OnLine Journal of Earth Sciences 4 (2): 72-79, 2010

ISSN: 1991-7708

(C) Medwell Journals, 2010

\title{
Geochemical and Geodynamic Implications of Mafic Dykes of the Iguerda Inlier (Central Anti-Atlas, Morocco)
}

\author{
${ }^{1}$ El Hassan, ${ }^{1}$ El Aouli and ${ }^{2}$ Hassan Amaouain \\ ${ }^{1}$ LAGAGE Laboratory, ${ }^{2}$ GESCAT Laboratory, \\ Department of Geology, Faculty of Sciences, Ibn Zohr University, \\ P.O. Box 8106, 80000 Agadir, Morocco
}

\begin{abstract}
In the inlier of Iguerda (Anti-Atlas, Morocco), the Neoproterozoic basic rocks consist dominantly of dolerite dykes intruded the Palæoproterozoic basement and overlain by the late Neoproterozoic series. Major and immobile trace elements (HFS and REE elements) allow to identify 2 groups of mafic rocks: the 1st is tholeiitic, the 2nd shows a transitional affinity with chondrite normalized REE patterns more fractionated. Their geochemical signatures display similarities with those of intraplate series found in young continental rift structures (they are enriched in incompatible elements, excepted $\mathrm{Y}$ and $\mathrm{Yb}$, relative to N-MORB but they are depleted in $\mathrm{Nb}$ ). This preorogenic magmatism can be related to begining of rifting in the northern border of the West-African craton which allows the emplacement of bassins of Pan-African belt of Anti-Atlas. This rifting may be related to the opening of an oceanic domain in Siroua and Bou-Azzer areas.
\end{abstract}

Key words: Mafic rocks, Neoproterozoic, Anti-Atlas (Morocco), tholeiitic, transitional, rifting

\section{INTRODUCTION}

The Anti-Atlas is a privileged domain for the study of mafic rocks as numerous mafic dykes swarms were emplaced over a period of time extending from the Palæoproterozoic (Gasquet et al., 2004) to the Jurassic. The Cryogenian mafic rocks analyzed during the present study are of particular interest because they formed on the Northern edge of the West African Craton (Pouclet et al., 2007) at the same that a back-arc basin was opening further east in the central Anti-Atlas as indicated by the presence of ophiolites at Bou Azzer and Siroua.

The main objective of the present study is to characterize the petrology and geochemistry and to propose a geodynamic setting for the emplacement of these Neoproterozoic mafic rocks within the more general framework of the Anti-Atlas and to investigate the relations between this magmatism and the pre-existing Pan-African and Eburnean subductions.

\section{GEOLOGICAL SETTING}

The Proterozoic basement of the Anti-Atlas is divided into 2 domains either side of the WNW-ESE oriented Central Anti-Atlas Fault Zone (CAAFZ) (Fig. 1). The northeastern domain has been interpreted as a multideformed Neoproterozoic Pan-African orogenic segment that encompasses the Siroua, Saghro and Ougnat massifs. However, the Neoproterozoic magmatism of this domain displays a Palæoproterozoic source suggesting an underlying Eburnean basement (Gasquet et al., 2005; Ennih and Liegeois, 2001). The Southwestern domain consists of a Palæoproterozoic and Neoproterozoic basement that was deformed by the Eburnean and PanAfrican orogenies and covered by Ediacaran to Paleozoic formations.

The Bou Azzer inlier lies between these 2 domains along the CAAFZ. This inlier consists mostly of a PanAfrican ophiolitic complex that has recently been dated at the neighboring Siroua massif at $761 \pm 2 \mathrm{Ma}(\mathrm{U} / \mathrm{Pb}$ on zircons from plagiogranites (Samson et al., 2004). The Igherm, Ifni and Kerdous inliers the focus of the present study belong to the southwestern domain on the Northern margin of the West-African Craton. No Mesoproterozoic ages have ever been found in the whole Anti-Atlas.

The Neoproterozoic of the Anti-Atlas has been divided into 2 supergroups; the Cryogenian Anti-Atlas Supergroup (AASG) and the ediacaran Ouarzazate Supergroup (OSG) (Thomas et al., 2004). The lower Cryogenian formations (Jbel Lkest Group, AASG pro parte) lie unconformably on the Palæoproterozoic basement (Gasquet et al., 2004). The bottom part of the AASG (limestones and quartzites) consists of epicontinental platform sediments whereas the upper

Corresponding Author: El Hassan, LAGAGE Laboratory, Department of Geology, Faculty of Sciences, Ibn Zohr University, P.O. Box 8106, Agadir 80000, Morocco 


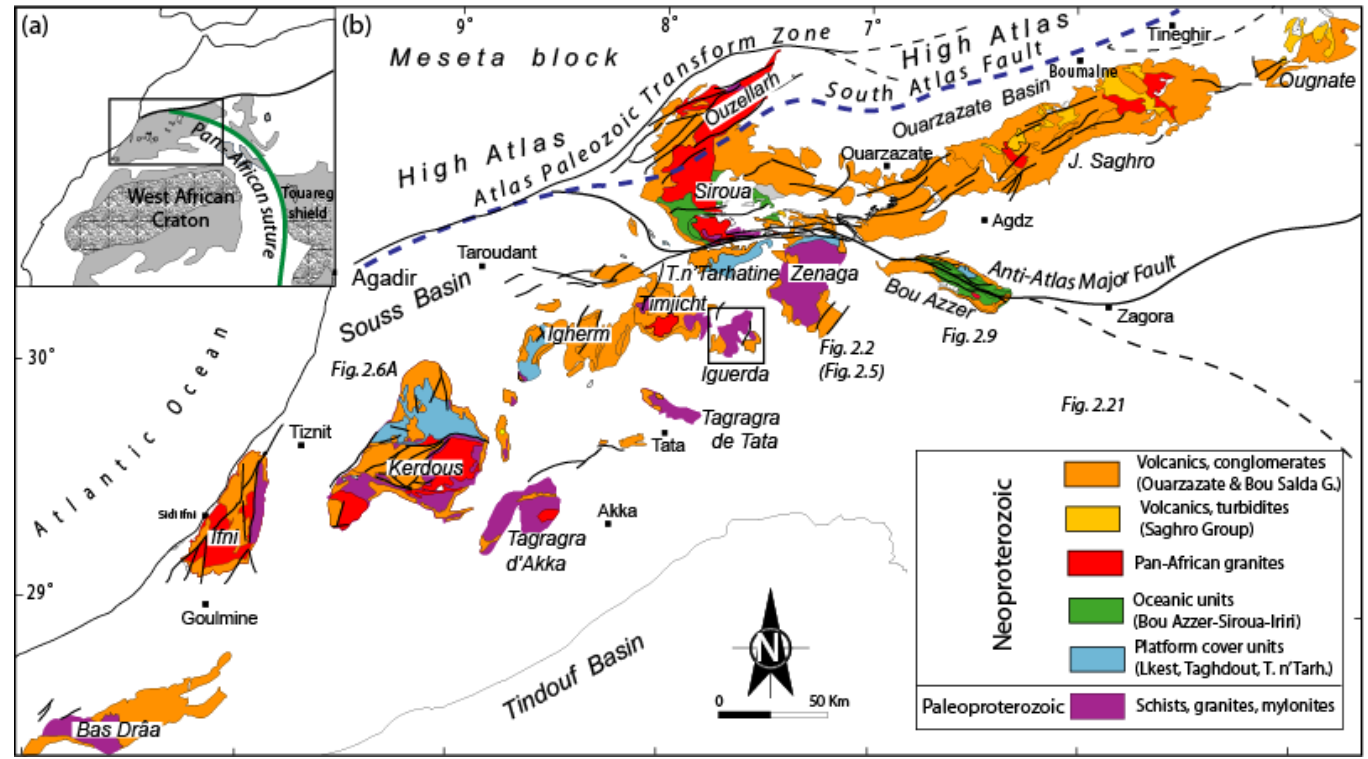

Fig. 1: Geological sketch map of the Anti-Atlas belt in southern Morocco and location of the studied inlier (bold square) SAF: South Atlas Fault

members (schists and stratified quartzites) are characteristic of an ocean basin environment. Mafic rocks have been described within all the Cryogenian sedimentary sequences of the AASG (Gasquet et al., 2004). The upper Cryogenian which records the late PanAfrican event is composed mostly of molassic conglomerates with rhyolites, ignimbrites and acid tufs at the base. The Ediacaran OSG formations consist of conglomerates overlain by purple-blue pelites preceded by andesitic flows in the northeastern part of the Igherm inlier and more generally across the Anti-Atlas by extremely thick (up to $2000 \mathrm{~m}$ in the Ouarzazate area) piles of felsic volcanic rocks (notably rhyolites).

The Palæoproterozoic of the Anti-Atlas consists of micaschists and calc-alkaline granites deformed during the Eburnean (Gasquet et al., 2005). Syn-orogenic granitoids developed after $2050 \mathrm{Ma}$, associated with calc-alkaline and peraluminous magmas derived from a mafic source (with a small Archaean crustal component) in a plateconvergence back-arc setting (Gasquet et al., 2004, 2005, 2008). According to the Palæoproterozoic in the AntiAtlas is characterized by two distinguishable magmatic events both related to a subduction setting: the first at 2110-2080 Ma (trondhjemitic magmatism) and the second at 2050-2030 Ma (calc-alkaline magmatism). Mafic magmatism in the Anti-Atlas is represented by at least four generations of dykes:

C Tholeiitic dykes of Palæoproterozoic age. Dykes in the Tagragra de Tata have been dated at $2040 \pm 6 \mathrm{Ma}$ using the SHRIMP $\mathrm{U} / \mathrm{Pb}$ method on zircons
(Walsh et al., 2002) and a microgranite from the Tafeltast inlier which is cartographically and structurally associated to the mafic dykes in this inlier and to those in the Tagragra d'Akka inlier, has been dated at $1760 \pm 3 \mathrm{Ma}$ (Gasquet et al., 2004)

C Cryogenian dykes with tholeiitic and alkaline affinities, coeval with the opening of back-arc oceanic basin in the Central Anti-Atlas (Clauer et al., 1982). U/Pb ages of $761 \pm 2 \mathrm{Ma}$ have been obtained using zircons from plagiogranites associated with the Siroua ophiolites (Samson et al., 2004)

C Dacite dykes in the Tafeltast and Tagragra d'Akka inliers, dated at $600 \pm 5 \mathrm{Ma}$ using the SHRIMP U/Pb method (Gasquet et al., 2004)

C Late Pan-African mafic dykes in cluding those that crosscut the Taourgha granite, dated at $575 \pm 4 \mathrm{Ma}$ (U/Pb ages) using samples from the Bas Draa inlier

The Iguerda inlier is located at $190 \mathrm{~km}$ E-SE to city of Agadir (Fig. 2) and is part with the Zenaga, Bou Azzer-El Grara inliers and Siroua massif of the Central Anti-Atlas. It belongs to the South West area and is located on the northern edge of the West African Craton. It consists by:

C A basement consisting of micaschist, gneiss, quartzdiorite, sometimes orbicular, granites and pegmatites attributed to the Palæoproterozoic (PI).This basement has great similarities with that of the Zenaga inliers in the East and Kerdous Southwest. The 


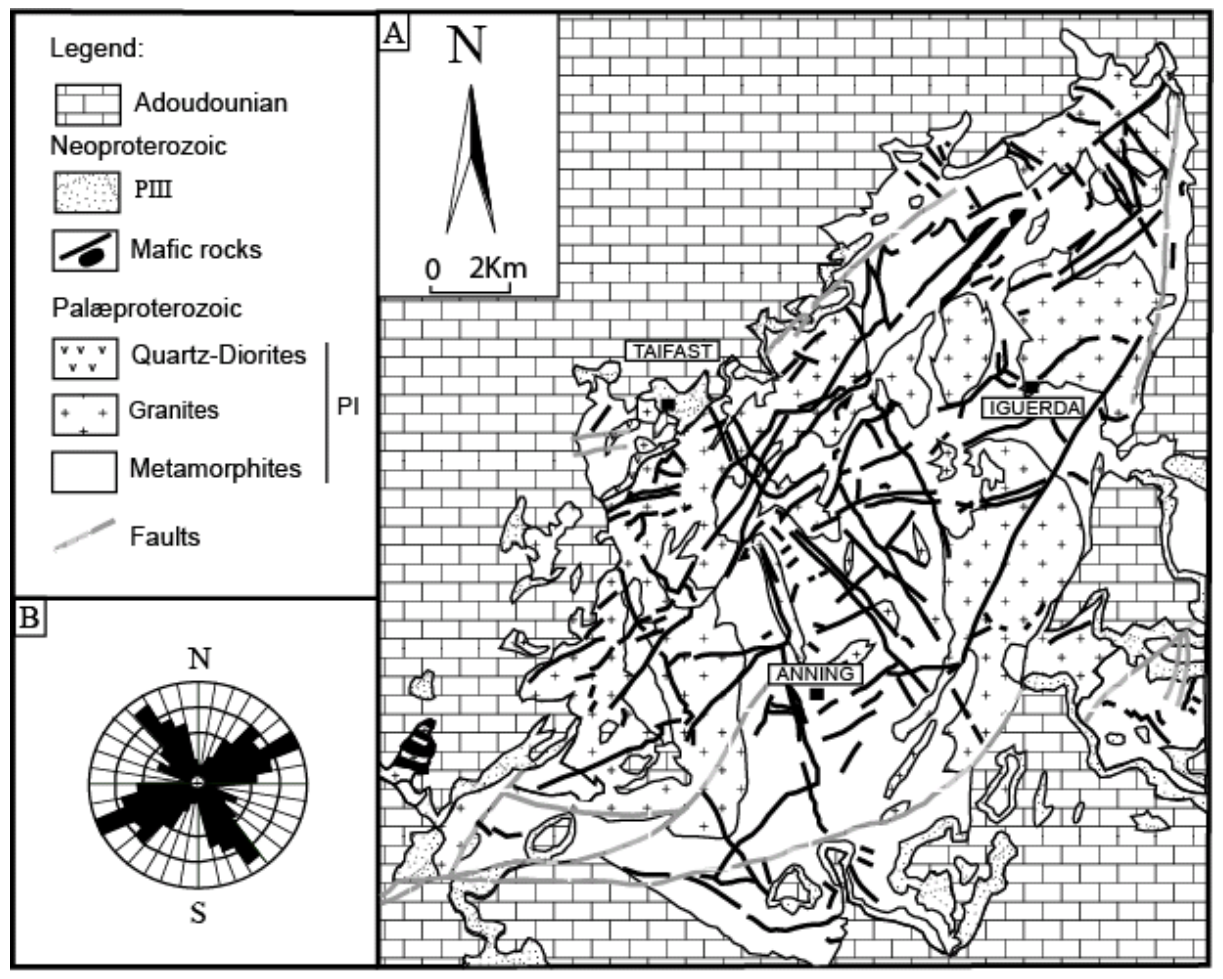

Fig. 2: A) Geological skech map of the inlier after the Geological map of Morocco (1/100 000, sheet Agadir Melloul). B) Rosace of deep of mafic dykes of the inlier Iguerda

analogy between these facies granites and those of Zenaga and Kerdous inliers shows that their age is also Palæoproterozoic

C Of dolerite dykes with various directions (N-NE and $\mathrm{NW}$ to N-NW) emplaced before the conglomeratic formations of the terminal Neoproterozoic (PIII). These dolerites belong, according to Agard and Choubert, a single magmatic and would come to the same age as those known in the Neoproterozoic (PII) of the Zenaga inlier and therefore predate the major phase of panafricain

C The red sedimentary formations (sandstone and conglomerates), pyroclastic (tuffs) and volcanic (rhyolite) in small synclinal folds flush to the east and north-west of the inlier. The age of these formations would be terminal Neoproterozoic (PIII)

\section{GEOLOGICAL SETTING OF THE MAFIC DYKES OF THE IGUERDA INLIER}

The mafic rocks studied are represented by dykes of diabases intrusive in the bassement formations (PI) consisting of granite, micaschist and schist injected. They never cut the volcano-sedimentary and volcanic formations of PIII and those of Adoudounian. The rocks outcrop in the form of numerous dykes ranging from
$\mathrm{N} 20-70^{\circ} \mathrm{E}$ and $\mathrm{N} 120-170^{\circ} \mathrm{E}$ and that range from several kilometers in length and from 2-100 $\mathrm{m}$ in width (Fig. 2) and is easily distinguished by their gray-green to reddish and outcrop along the borders of inlier and generally very altered balls more or less angular. According to Bilal and Derre, their emplacement is after the two Pan-African strains, major $(685 \mathrm{Ma})$ and late $(615 \mathrm{Ma})$, affecting the granites and Pegmatites (PI). However, the observations show that these dykes are affected such as shale and granite of bassement by at least 2 regional schistosity, respectively oriented N50 at $65^{\circ} 80^{\prime} \mathrm{NW}$ and N160 $80^{\prime} \mathrm{E}$. Sometimes, their borders are schistosed a thickness varying from a few centimeters to $2 \mathrm{~m}$ as if these limits were used sills enclosing plans shears later emplacement. The footwall dykes oriented N65 $80^{\prime} \mathrm{W}$ show sigmoidal tension gashes filled with quartz and calcite, related to sinistral decrochement N45. These structural data confirm the findings of and used to assign an earlier Pan-African major age for these dykes.

\section{PETROGRAPHY}

The mafic rocks have a intersertal texture and mineralogical paragenesis characterized by laths of plagioclase saussuritized and albitized (Ab 96-99\%), pyroxene ( $\mathrm{Ca} 41-44 \%, \mathrm{Mg} 36-42 \%$ and $\mathrm{Fe} 17-21 \%$ ) 
uralitized, probably olivines pseudomorphosed in iddingsite and chlorite, opaque minerals including partially or totally plagioclase and pyroxene and crystallized in the interstices, apatite and interstitial quartz in the facies evolved. These minerals have undergone secondary transformations in facies greenschist resulting from an assembly albite, chlorite, actinolite, epidote, iron oxides and quartz.

\section{GEOCHEMICAL CHARACTERIZATION}

Representative chemical analysis of the least altered rocks in this inlier are shown in Table 1. The use of certain elements such as $\mathrm{TiO}_{2}$, trace elements $(\mathrm{Nb}, \mathrm{Zr}, \mathrm{Y}$ and V) and rare earths, deemed not very mobile during the different processes of hydrothermal or metamorphism alteration (Pearce and Cann, 1973; Floyd and Winchester, 1975) allowed to subdivide these rocks, regardless of the directions mentioned before in 2 groups.

Group 1 which is characterized by relatively low contents of $\mathrm{TiO}_{2}$ (1.37-2.98\%), Zr (75-209 ppm), Nb (5.5-12.6 ppm), Y (18.8-31.7 ppm), V (229- 447 ppm) and low $\mathrm{La} / \mathrm{Nb}(0.83-2.38)$. The $\mathrm{Y} / \mathrm{Nb}>2$ (2.28-3.88) reflect the tholeiitic affinity of this group (Floyd and Winchester, 1975). The REE patterns (Evensen et al., 1978) are sub-flat and parallel (Fig. 3) reflecting different degrees of differentiation and cogenetic original magma. The $(\mathrm{La} / \mathrm{Sm}) \mathrm{N}$ and $(\mathrm{La} / \mathrm{Yb}) \mathrm{N}$ ranging between 1.14 and 2.41,

Tab. 1: Representative analysis of mafic rocks from the Iguerda inlier (Analysis from CRPG (Nancy) by ICP-AES (major and minor elements) and ICP-MS

\begin{tabular}{|c|c|c|c|c|c|c|c|c|}
\hline \multirow[b]{2}{*}{$\mathrm{N}^{\circ}$ Sample } & \multicolumn{4}{|c|}{ Group 1} & \multicolumn{4}{|c|}{ Group 2} \\
\hline & IGU 15 & IGU 41 & IGU 33 & IGU 12 & IGU 9 & IGU 11 & IGU 54 & IGU 44 \\
\hline $\mathrm{SiO}_{2}$ & 46.56 & 47.00 & 47.72 & 49.04 & 45.80 & 46.45 & 46.60 & 46.65 \\
\hline $\mathrm{Al}_{2} \mathrm{O}_{3}$ & 14.17 & 14.10 & 13.46 & 14.27 & 14.26 & 12.69 & 13.14 & 13.38 \\
\hline $\mathrm{TiO}_{2}$ & 1.74 & 2.96 & 2.98 & 2.49 & 3.40 & 3.62 & 3.58 & 3.59 \\
\hline $\mathrm{Fe}_{2} \mathrm{O}_{3} \mathrm{t}$ & 14.36 & 17.20 & 16.12 & 14.70 & 17.92 & 18.55 & 19.00 & 18.90 \\
\hline $\mathrm{MnO}$ & 0.22 & 0.31 & 0.31 & 0.28 & 0.16 & 0.22 & 0.21 & 0.22 \\
\hline $\mathrm{MgO}$ & 7.31 & 5.66 & 6.09 & 5.60 & 6.51 & 4.42 & 4.52 & 4.55 \\
\hline $\mathrm{CaO}$ & 6.82 & 5.30 & 4.95 & 4.44 & 4.72 & 5.55 & 5.55 & 5.54 \\
\hline $\mathrm{Na}_{2} \mathrm{O}$ & 3.92 & 3.30 & 3.73 & 4.01 & 2.43 & 2.67 & 2.61 & 2.61 \\
\hline $\mathrm{K}_{2} \mathrm{O}$ & 1.41 & 1.01 & 1.12 & 1.11 & 0.60 & 0.96 & 0.98 & 0.98 \\
\hline $\mathrm{P}_{2} \mathrm{O}_{5}$ & 0.21 & 0.32 & 0.29 & 0.28 & 0.52 & 0.70 & 0.60 & 0.60 \\
\hline P.F & 3.31 & 2.67 & 2.91 & 3.49 & 3.63 & 3.77 & 2.99 & 2.92 \\
\hline Total & 100.03 & 99.80 & 99.68 & 99.71 & 99.95 & 99.87 & 100.00 & 99.94 \\
\hline $\mathrm{Ba}$ & 66.00 & 670.00 & 900.00 & 854.00 & 499.00 & 1096.00 & 1007.00 & 1022.00 \\
\hline $\mathrm{Be}$ & 0.49 & 0.79 & 1.06 & 0.96 & 0.73 & 1.60 & 0.72 & 1.13 \\
\hline $\mathrm{Co}$ & 54.90 & 59.60 & 59.50 & 71.80 & 56.08 & 70.10 & 60.90 & 61.30 \\
\hline $\mathrm{Cr}$ & 212.00 & 64.00 & 74.00 & 69.00 & 77.00 & 9.00 & 7.00 & 9.00 \\
\hline $\mathrm{Ga}$ & 19.20 & 25.00 & 22.30 & 22.50 & 22.91 & 26.10 & 26.50 & 27.06 \\
\hline $\mathrm{Cu}$ & 37.70 & 11.70 & 9.60 & 8.70 & 8.39 & 10.90 & 9.74 & 12.35 \\
\hline $\mathrm{Ni}$ & 107.00 & 61.00 & 104.00 & 60.00 & 70.00 & 35.00 & 32.00 & 33.00 \\
\hline $\mathrm{Nb}$ & 6.10 & 11.50 & 12.62 & 12.40 & 16.96 & 22.58 & 20.90 & 21.44 \\
\hline $\mathrm{Rb}$ & 24.04 & 44.30 & 50.07 & 51.48 & 14.25 & 27.71 & 23.60 & 24.44 \\
\hline $\mathrm{Sr}$ & 158.00 & 404.00 & 302.00 & 356.00 & 298.00 & 521.00 & 525.00 & 527.00 \\
\hline V & 349.00 & 447.00 & 434.00 & 322.00 & 304.00 & 340.00 & 339.00 & 346.00 \\
\hline $\mathrm{Zn}$ & 172.00 & 193.00 & 210.00 & 196.00 & 195.00 & 218.00 & 238.00 & 242.00 \\
\hline $\mathrm{Zr}$ & 99.00 & 156.00 & 173.00 & 144.00 & 195.00 & 272.00 & 262.00 & 265.00 \\
\hline $\mathrm{Th}$ & 0.48 & 1.10 & 1.11 & 1.16 & 3.14 & 3.11 & 4.50 & 4.54 \\
\hline $\mathrm{Y}$ & 23.70 & 31.70 & 28.80 & 28.90 & 29.19 & 42.60 & 40.10 & 40.87 \\
\hline $\mathrm{U}$ & 0.13 & 0.23 & 0.24 & 0.24 & 0.52 & 0.69 & 0.69 & 0.72 \\
\hline $\mathrm{La}$ & 6.77 & 14.50 & 10.51 & 12.67 & 29.68 & 44.10 & 43.40 & 43.93 \\
\hline $\mathrm{Ce}$ & 17.17 & 35.30 & 26.67 & 31.08 & 65.86 & 98.66 & 94.50 & 98.66 \\
\hline $\mathrm{Nd}$ & 12.50 & 23.90 & 16.83 & 20.57 & 35.98 & 51.56 & 51.40 & 53.37 \\
\hline $\mathrm{Sm}$ & 3.73 & 6.39 & 4.71 & 5.52 & 7.18 & 11.01 & 10.80 & 10.99 \\
\hline $\mathrm{Eu}$ & 1.10 & 2.09 & 1.52 & 1.87 & 2.36 & 3.57 & 3.31 & 3.43 \\
\hline $\mathrm{Gd}$ & 3.67 & 6.19 & 4.67 & 5.06 & 6.58 & 9.40 & 9.60 & 9.40 \\
\hline Dy & 4.03 & 5.47 & 4.79 & 5.11 & 5.56 & 7.64 & 7.26 & 7.78 \\
\hline $\mathrm{Er}$ & 2.18 & 2.89 & 2.53 & 2.55 & 2.84 & 3.85 & 3.83 & 3.90 \\
\hline $\mathrm{Yb}$ & 2.13 & 2.79 & 2.55 & 2.56 & 2.59 & 3.55 & 3.71 & 3.72 \\
\hline $\mathrm{Lu}$ & 0.32 & 0.41 & 0.38 & 0.39 & 0.45 & 0.59 & 0.58 & 0.63 \\
\hline $\mathrm{Y} / \mathrm{Nb}$ & 3.88 & 2.75 & 2.28 & 2.33 & 1.72 & 1.88 & 3.89 & 1.91 \\
\hline $\mathrm{Ti} / \mathrm{V}$ & 29.91 & 39.70 & 41.19 & 46.39 & 66.90 & 63.88 & 29.90 & 62.18 \\
\hline $\mathrm{La} / \mathrm{Nb}$ & 1.10 & 1.26 & 0.83 & 1.02 & 1.75 & 1.95 & 1.11 & 2.05 \\
\hline${ }^{(\mathrm{La} / \mathrm{Sm})} \mathrm{N}$ & 1.14 & 1.43 & 1.40 & 1.44 & 2.60 & 2.52 & 1.14 & 2.52 \\
\hline${ }^{(\mathrm{L} a / Y \mathrm{~b})} \mathrm{N}$ & 2.14 & 3.51 & 2.78 & 3.34 & 7.75 & 8.38 & 2.15 & 7.99 \\
\hline${ }^{(\mathrm{Gd} / \mathrm{Yb})} \mathrm{N}$ & 1.40 & 9.65 & 1.49 & 1.61 & 2.07 & 2.15 & 11.30 & 2.06 \\
\hline
\end{tabular}


OnLine J. Earth Sci., 4 (2): 72-79, 2010

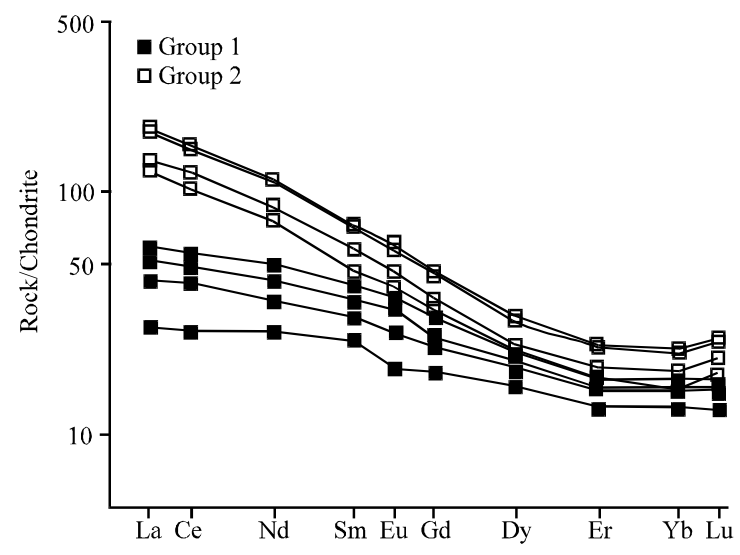

Fig. 3: Chondrite-normalized rare earth element patterns (Evensen et al., 1978) for the two groups of mafic rocks from the Iguerda inlier

respectively and 2.14 and 4.50 show a slight LREE enrichment of the rocks of this group. The enrichment of iron (12.77-18.55\%) and titanium (1.37-2.98\%) parallel to the differentiation index $\mathrm{FeO} * \mathrm{MgO}(1.74-2.81)$ confirms the tholeiitic character of this group (Miyashiro, 1974; Miyashiro and Shido, 1975) while the concomitant increase in $\mathrm{TiO}_{2}$ and $\mathrm{FeO} * / \mathrm{MgO}$ reflects the typical anisotitanium character of anorogenic areas (Fig. 4). The reports of $\mathrm{Ti} / \mathrm{V}$ are between 20 and 50 (22.38-46.39) and are typical, according to MORB or to back-arc basins basalts (Fig. 5).

Group 2 is characterized by comparison with the previous group with relatively high contents of $\mathrm{TiO}_{2}$ (3.40-3.62\%), $\mathrm{Y}(29.2-42.6 \mathrm{ppm}), \mathrm{P}_{2} \mathrm{O}_{5}(0.520 .7 \%)$ and $\mathrm{Nb}$ (17-22.6 ppm). The reports $1<\mathrm{Y} / \mathrm{Nb}<2(1.71-1.91)$ show the transitional affinity of the group (Floyd and Winchester, 1975). The REE (Evensen et al., 1978) are relatively enriched in LREE $\left((\mathrm{La} / \mathrm{Sm})_{\mathrm{N}}=2.34-2.60\right)$ and slightly depleted in HREE $\left((\mathrm{La} / \mathrm{Yb})_{\mathrm{N}}=7.56-8.38\right.$ and $(\mathrm{Gd} / \mathrm{Yb})_{\mathrm{N}}=$ 1.98-2.14) (Fig. 4). Ti/V ranging between 50 and 70 (62.18-66.90) are comparable to those of transitional basalts (Shervais, 1982) (Fig. 5). The values of the number $\mathrm{Mg}\left(\mathrm{Mg} \#=100 \mathrm{Mg} / \mathrm{Mg}+\mathrm{Fe}^{2+} ; 33-51\right)$ and low Ni contents $(<107 \mathrm{ppm}), \mathrm{Cr}(<86 \mathrm{ppm})$ and $\mathrm{Co}(<72 \mathrm{ppm})$ reflect the relative differential rocks studied. The terms of the less evolved (sample IGU 15 for group 1 and sample IGU9 for group 2) can not be considered representative of liquids primitive derived directly from the partial melting. The absence of accessory minerals that may cause fractionation of LREE relative to HREE and the difference in the degree of fractionation of REE in both groups confirms what has been demonstrated by the study of trace element and excluded any genetic relationship by fractional crystallization between the two groups. The differentiation process are controlled by fractionation

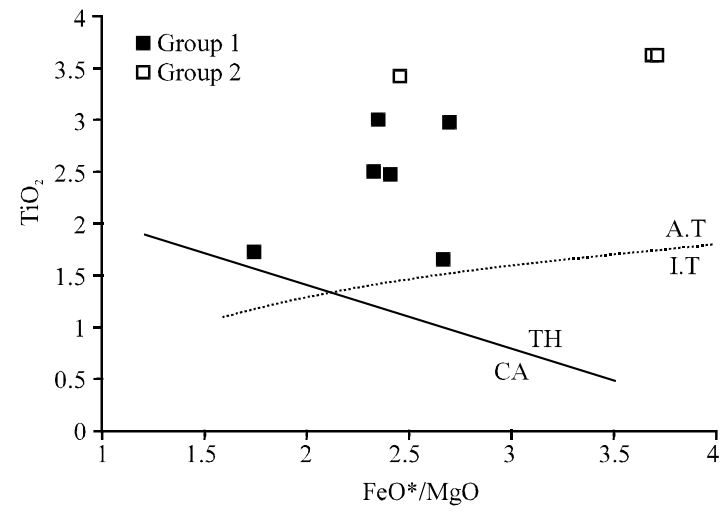

Fig. 4: $\mathrm{TiO}_{2}$ vs $\mathrm{FeO} * / \mathrm{MgO}$ diagram (Miyashiro and Shido, 1975) for the mafic rocks from the Iguerda inlier. The A.T (anisotitanium) and I.T (isotitanium) are after Bebien

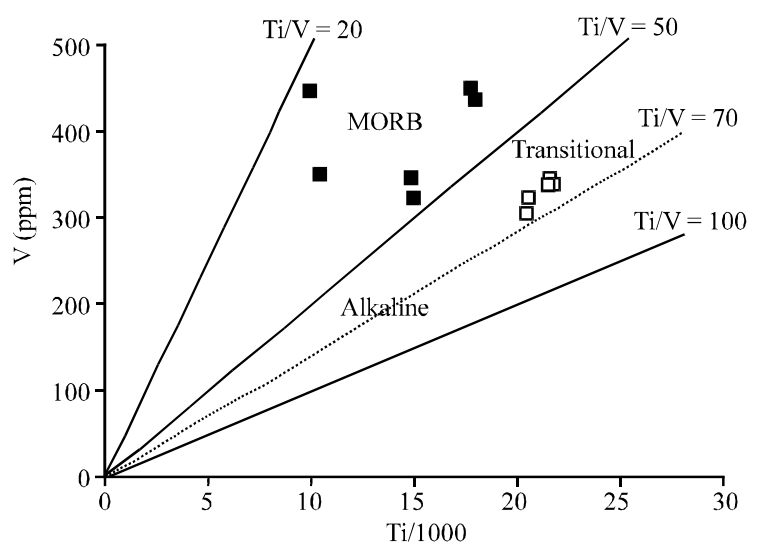

Fig. 5: V vs Ti/1000 diagram (Shervais, 1982) for the mafic rocks from the Iguerda inlier

of plagioclase and pyroxene ( \pm olivine) which explains the decrease of $\mathrm{CaO}, \mathrm{Al}_{2} \mathrm{O}_{3}$ and the concomitant enrichment of LREE and HREE resulting in a parallel patterns within each group. The late onset of the oxides resulting ferrotitanium enhancements observed for iron and titanium.

\section{GEODYNAMIC FRAMEWORK}

Normalized to MORB of Pearce (1982) (Fig. 6), the rocks of group 1 are enriched in all incompatible elements of $\mathrm{Sr}$ to Ti relative to $\mathrm{Y}, \mathrm{Yb}, \mathrm{Sc}$ and $\mathrm{Cr}$. They are similar in this, to intraplate lavas with tholeiitic affinity. Whereas group 2, compared with the previous group is relatively enriched in incompatible elements of $\mathrm{Nb}$ to $\mathrm{Ti}$ in addition to its strong enrichment in the most incompatible elements $(\mathrm{Ba}, \mathrm{Th}$ and $\mathrm{Ta}$ ) and a slight negative $\mathrm{Nb}$ anomaly. These intermediate characters confirm the transitional affinity of 
this group. The normalization to primitive mantle of Sun and McDonough (1989) confirms the character intracontinental, respectively tholeiitic and transitional in these 2 groups of rocks. The first group coincides with the continental tholeiite referenced by Holm (1985) while the second group is similar to Ocean Island Basalts (OIB) and is distinguished from the latter by the absence of a marked enrichment in $\mathrm{Nb}$ (Fig. 7). By their tholeiitic geochemical affinity and anorogenic intraplate and anisotitanium character, mafic rocks of group 1 are comparable to those Bas Draa and Tagragra Akka inliers and some mafic rocks of their counterparts of Igherm inlier in the western Anti-Atlas. They are also comparable to the mafic rocks of the Siroua massif in the central AntiAtlas and to the lower Neoproterozoic basalts (lower PII) of Kelaat Mgouna (Saghro) in the East Anti-Atlas. In

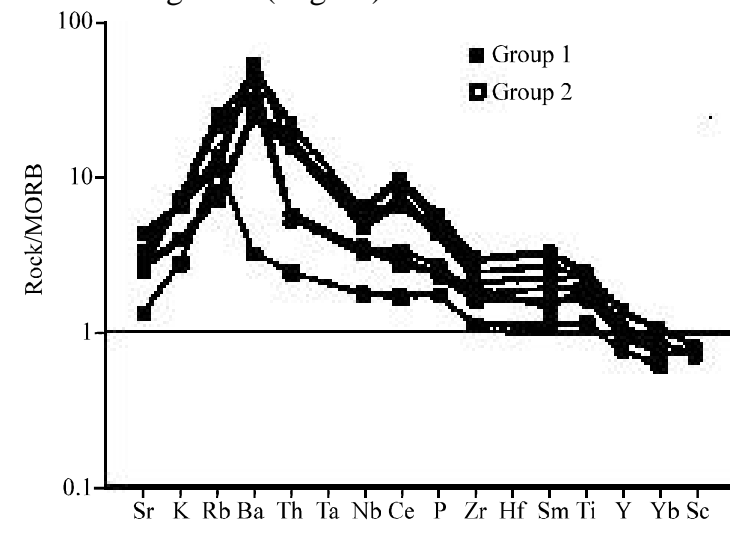

Fig. 6: MORB-normalized spiderdiagram (Pearce, 1982) for 2 groups of mafic rocks from the Iguerda inlier

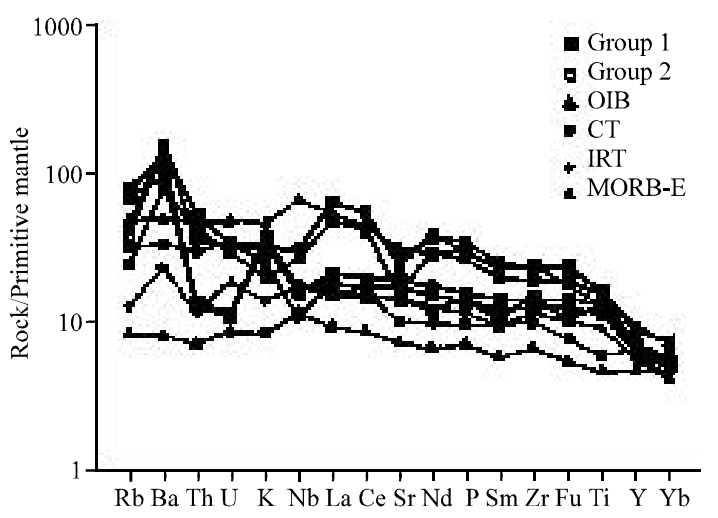

Fig. 7: Mantle primordial-normalized spiderdiagram (Sun and McDonough, 1989) and comparaison of the Iguerda mafic rocks with the enriched MORB (MORB-E), Continetal Tholeiites (CT) in Itial Rifting Tholeiites (IRT) and the island Oceanic Basalt (OIB). Data of reference samples are from Holm (1985) contrast, mafic rocks of group 2 to transitional affinities are comparable to some mafic rocks of similar age in the Siroua massif.

\section{DISCUSSION}

The coexistence of these 2 types of mafic magmatism (tholeiitic and alkaline or tholeiitic and transitional is a common phenomenon in the upper Proterozoic to inliers of the central and Western Anti-Atlas.

The pre-orogenic mafic magmatism of Neoproterozoic (lower PII) of the southwestern domain Anti-Atlas has many similarities with that of areas on the edges of cratons in the southern hemisphere. In the Zambezi belt that separates the Congo craton and the Kalahari, Munyanyiwa et al. (1997) showed mainly tholeiitic mafic magmatism (occasionally alkaline or transitional) or bimodal pre-orogenic nature, formed in a continental rift zone.

This rift is heralding the creation of a basin in which are accumulated sequences of Neoproterozoic Zambezi. In the bassins of Comba and Sembe-Ouesso (Congo), diabase intrusions associated with sedimentation dated 1 Ga to $900 \mathrm{Ma}$ are attributed to a continental rift system.

They belong to a tholeiitic series weakly alkaline intraplate characteristic of continental rifts formed by the ascent of the asthenosphere. These intrusions extend to the north in regions of lower Dja in Yokadouma (Cameroon) and Nola (RCA) where fissural magmatism of Neoproterozoic series is represented by a complex diabase of continental tholeiites nature. This magmatism is attributed to a rift system on the northern border of the Congo Craton related to intracontinental extension of the Congo Craton.

The magmatism of the northern border of West African Craton which includes the domain southwestern Anti-Atlas is part of the pre-orogenic evolution responsible of rifting with depending on the regions, evolved or not to oceanisation. These rifting that led to the installation of ocean basins became the headquarters building of the Pan-African chains.

However, it should be noted that the Proterozoic of the Anti-Atlas recorded a gap of sedimentation about $1 \mathrm{Ga}$. If the age of contact metamorphism induced by mafic intrusive bodies in the series of shales, limestones and quartzites (788 Ma; Clauer et al., 1982) can assign the mafic magmatism to the early stages of the cycle PanAfrican, this does not exclude that among the dykes which intrude the Palæoproterozoic basement of the AntiAtlas there is no seams that can be attributed to a period after that period gap well represented further east as in the Hoggar (quartzitic series of Ahnet and associated 
volcanism) from. In addition, the fissural mafic magmatism of the domain Southwestern Anti-Atlas not can be attached in full to the pre-orogenic episode of the Panafrican chain.

Indeed, a mafic magmatism attributed to the Neoproterozoic extensional event was recognized in the massif of Baa Draa.

This magmatism is represented by diabases dykes intrusive into the post-tectonic granite of Taourgha dated at $575 \pm 4$ Ma.

\section{CONCLUSION}

In the Iguerda inlier, the petrographic and geochemical study of mafic rocks of Neoproterozoic (PII) has established a relative chronology of mafic magmatism in this part of the central Anti-Atlas with respect to the training of Palæoproterozoic bassement (PI) and formations of the terminal formations Neoproterozoic (PIII) and lower Cambrian.

In addition, in comparison with their counterparts in others inliers of the western Anti-Atlas, we could place these diabases within the global geodynamic evolution of the Anti-Atlas.

Total 2 groups unequally developed in the inlier and independent from the trend were distinguished; a group with tholeiitic affinity and isotitanium character implemented in a intraplate anorogenic domain; a group less abundant than the preceding and which is distinguished by its transitional character.

The mafic magmatism, attached to the Neoproterozoic in the inlier has many similarities with that of Siroua massif (central Anti-Atlas) and the other inliers of the western Anti-Atlas (Igherm, Bas Draa and Tagragra d'Akka ). Its Geodynamic framework could be linked to an extensive context marking the pre-Pan-African rifting in this area of the central Anti-Atlas part of the northern edge of the West African craton and recognized for the same geological period from ophiolites Bou Azzer and Siroua.

\section{ACKNOWLEDGEMENTS}

This study was supported by a scientific frenchmoroccan cooperation grant awarded by the CNRSCNRST (SHS05/07) to EDYTEM, UMR-CNRS 5204 (University of Savoie, Chambery) and LAGAGE (University Ibn Zohr, Agadir). Researcher would like to thank anonymous reviewer for their critical and constructive comments of the manuscript. Their comments led to many improvements in the quality and clarity of the english text.

\section{REFERENCES}

Clauer, N., R. Caby, E. Jeannette and R. Trompette, 1982. Geochronology of sedimentary and metasedimentary precambrian rocks of the west african craton. Precambrain Res., 18: 53-71.

Ennih, N. and J.P. Liegeois, 2001. The Moroccan antiatlas: The West African craton passive margin with limited Pan-African activity. Implications for the northern limit of the craton. Precambrain Res., 112: 289-302.

Evensen, M., J. Hamilton and R.K. O'Nions, 1978. Rare earth abundances in chondritic meteorites. Geochimica Cosmochimica Acta, 42: 1199-1212.

Floyd, P.A. and J.A. Winchester, 1975. Magma type and tectonic setting descrimination using immobile elements. Earth Planet. Sci. Lett., 27: 211-218.

Gasquet, D., G. Levresse, A. Cheilletz, M.R. Azizi-Samir and A. Mouttaqi, 2005. Contribution to a geodynamic reconstruction of the Anti-Atlas (Morocco) during Pan-African times with the emphasis on inversion tectonics and metallogenic activity at the Precambrian-Cambrian transition. Precambrain Res., 140: 157-182.

Gasquet, D., N. Ennih, J.P. Liegeois, A. Soulaimani and A. Michard, 2008. The Panafrican Belt. In: Continental Evolution: The Geology of Morocco. Structure, Stratigraphy and Tectonics of the Africa-AtlanticMediterranean Triple Junction, Michard, A., O. Saddiqi, A. Chalouan and D.F. de Lamotte (Eds.). Springer-Verlag, Berlin, Heidelberg, pp: 33-64.

Gasquet, D., P. Chevremont, T. Baudin, F. Chalot-Prat and C. Guerrot et al., 2004. Polycyclic magmatism in the Tagragra d'Akka and Kerdous-Tafeltast inliers (Western Anti-Atlas, Morocco). J. Afr. Earth Sci., 39: 267-275.

Holm, P.E., 1985. The geochimical finger-print of different tectonomagmatic environments using hygromagmaphile element abundances of tholeiitic basalts and basaltic andesites. Chem. Geol., 51: 303-323.

Miyashiro, A. and F. Shido, 1975. Tholeiitic and calcalcaline series in relation to the behaviors of titanium, vanadium, chromium and nickel. Am. J. Sci., 275: 265-277.

Miyashiro, A., 1974. Volcanic rock series in island arcs and active continental margins. Am. J. Sci., 274: 321-355.

Munyanyiwa, H., R.E. Hanson, T.G. Blenkinsop and P.J. Treloar, 1997. Geochemistry of amphibolites and quartzofeldspathic gneisses in the Pan-African Zambezi belt, northwest Zimbabwe: Evidence for bimodal magmatism in a continental rift setting. Precambrain Res., 81: 179-196. 
Pearce, J.A. and J.R. Cann, 1973. Tectonic setting of basic volcanic rocks determined using trace elements analysis. Earth Planetary Sci. Lett., 19: 290-300.

Pearce, J.A., 1982. Trace Element Characteristics of Lavas Destructives Plate Boundaries. In: Andesites: Orogenic Andesites and Related Rocks, Thorphe, R.S. (Ed.). John Willey and Sons, UK., pp: 525-548.

Pouclet, A., A. Aarab, A. Fekkak and M. Benharref, 2007. Geodynamic evolution of the northwestern paleogondwanan margin in the moroccan atlas at the precambrian-cambrian boundary. GSA Special Papers, 423: $27-60$.

Samson, S.D., J.D. Inglis, R.S. D'Lemos, H. Admou, J. Blichert-Toft and K. Hefferan, 2004. Geochronological, geochemical and Nd-Hf isotopic constraints on the origin of Neoproterozoic plagiogranites in the Tasriwine ophiolite, Anti-Atlas orogen, Morocco. Precambrain Res., 135: 133-147.
Shervais, J.W., 1982. Ti-V plots and the petrogenesis of modern and ophiolite lavas. Earth Planetary Sci. Lett., 59: 101-118.

Sun, S.S. and W.F. McDonough, 1989. Chemical and isotopic systematics of oceanic basalts: Implications for mantle composition and processes. Geological Society London, 42: 313-345.

Thomas, R.J., A. Fekkak, N. Ennih, E. Errami and S.C. Loughlin et al., 2004. A new lithostratigraphic framework for the Anti-Atlas Orogen, Morocco. J. Afr. Earth Sci., 39: 217-226.

Walsh, G.J., J. Aleinikoff, F. Benziane, A. Yazidi and T.R. Amstrong, 2002. U-Pb zircon geochronology of the Palæoproterozoic Tagragra de Tata inlier and its Neoproterozoic cover, Western Anti-Atlas, Morocco. Precambrain Res., 117: 1-20. 